International Journal of Behavioral Research \& Psychology (IJBRP)

ISSN 2332-3000

\title{
White-collar Crimes in Kashmir, J\&K - A Systematic Review Study on White-collar Crime, Criminal Behavior and its Consequences
}

Review Article

Shekhar $\mathrm{C}^{1 *}$, Showkat $\mathrm{G}^{2}$

${ }^{1}$ Assistant Professor, Department of Psychology, University of Jammu, J\&K, India.

${ }^{2}$ Contractual lecturer, Department of Psychology, University of Kashmir Hazratbal, J\&K, India.

\begin{abstract}
White-collar crime as moral or ethical violations follows ideals inherent within the principles of natural law. Natural law focuses on behaviors or activities that are defined as wrong because they violate the ethical principles of a particular culture, subculture, or group. The immoral nature of the activities is seen as the foundation for defining certain types of white-collar activities as criminal. Some prefer to call white-collar crime as violations of criminal law. White-collar crimes are criminally illegal behaviors committed by upper class individuals during the course of their occupation. From a systems perspective, those working in the criminal justice system would likely define white-collar crime as criminally illegal behaviors. Crime, in this context, is defined as "an intentional act or omission committed in violation of the criminal law without defense or justification and sanctioned by the state as a felony or misdemeanor" (Tappan, 1960, p. 10). The consequences of white-collar crime can be characterized as; individual economic losses, societal economic losses, emotional consequences, physical harm and positive consequences as well. Research on white-collar crime attitudes is important for empirical, cultural, and policy-driven reasons (Piquero, Carmichael, \& Piquero, 2008). Because white-collar offenses are viewed as equally serious as street crimes, there may be a tendency among some to view white-collar criminals as similar to street criminals (Payne, 2003b). Many crime prevention programs work. Others don't. Most programs have not yet been evaluated with enough scientific evidence to draw conclusions. Enough evidence is available, however, to create provisional lists of what works, what doesn't and what's promising. Those lists will grow more quickly if the Nation invests more resources in scientific evaluations to hold all crime prevention programs accountable for their results. Both crime and criminal have become the focus of attention in the present day Kashmiri society. It is a regrettable fact that we have not so far undertaken comprehensive macro and micro level studies of crimes in Kashmir which could have facilitated a better understanding of its causes and effects and help to devise proper remedial measures. It is evident from the facts that white-collar crimes in Kashmir are increasing day by day. There are multiple causes of white-collar crimes in Kashmir. The consequences of white-collar crime can be characterized as (1) individual economic losses, (2) societal economic losses, (3) emotional consequences, (4) physical harm and (5) "positive" consequences. Research on white-collar crime attitudes is important for empirical, cultural, and policy-driven reasons (Piquero, Carmichael, \& Piquero, 2008).
\end{abstract}

Keywords: White-Collar Crime; Criminal Behavior; Criminal Law; Consequences And Crime Prevention.

\section{*Corresponding Author:}

Chandra Shekhar,

Assistant Professor, Department of Psychology, University of Jammu,

Jammu and Kashmir, India.

E-mail: dr.cschandra@gmail.com

Received: June 01, 2014

Accepted: July 10, 2014

Published: July 25, 2014

Citation: Shekhar C, Showkat G (2014) White-collar Crimes in Kashmir, J\&K - A Systematic Review Study on White-collar Crime, Criminal Behavior and its Consequences. . Int J Behav Res Psychol. 2(6), 59-64. doi: http://dx.doi.org/10.19070/2332-3000-1400011

Copyright: Shekhar $\mathbf{C}^{\mathcal{O}}$ 2014. This is an open-access article distributed under the terms of the Creative Commons Attribution License, which permits unrestricted use, distribution and reproduction in any medium, provided the original author and source are credited.

\section{Introduction}

Crime committed by a person of respectability and high social status in the course of his occupation is called white-collar crime (Sutherland1949). The purpose of the concept of white-collar crime is to call attention to a vast area of criminal behavior which is generally overlooked as criminal behavior, which is seldom brought within the score of the theories of criminal behavior, and which, when included, call for modifications in the usual the- ories of criminal behavior. Defining white-collar crime as moral or ethical violations follows ideals inherent within principles of what is known as natural law. Natural law focuses on behaviors or activities that are defined as wrong because they violate the ethical principles of a particular culture, subculture, or group. Some prefer to define white-collar crime as violations of criminal law. From this framework, white-collar crimes are criminally illegal behaviors committed by upper class individuals during the course of their occupation. From a systems perspective, those working in the criminal justice system would likely define white-collar crime as criminally illegal behaviors. Crime, in this context, is defined as "an intentional act or omission committed in violation of the criminal law without defense or justification and sanctioned by the state as a felony or misdemeanor" (Tappan, 1960, p. 10). Applying a criminal law definition to white-collar crime, white-collar crimes are those criminally illegal acts

Committed during the course of one's job. Some examples are: An accountant embezzles funds from his employer; two nurses steal drugs from their workplace and sell them to addicts, a financial investor steals investors' money. a prosecutor accepts a bribe to drop criminal charges, two investors share inside information that allows them to redirect their stock purchases a disgruntled employee destroys the computer records of a firm upon his/her resignation. These acts are instances where the criminal law has been violated during the course of employment. 
Certainly, some rule breaking during the course of employment does not rise to the level of criminal behavior, but it may violate civil laws. Consequently, some may define white-collar crime as violations of civil law. Consider cases of corporate wrongdoing against consumers. In those situations, it is rare that the criminal law would be used to respond to the offending corporation. More often, cases are brought into the civil justice system.

Individuals have also defined white-collar crime as violations of regulatory law. Some workplace misdeeds might not violate criminal or civil laws, but may violate a particular occupation's regulatory laws. Most occupations and businesses have standards, procedures and regulations that are designed to administratively guide and direct workplace activities. The nursing home industry provides a good example. The government has developed a set of standards that nursing home administrators are expected to follow in providing care to nursing home residents. At different times during the year, government officials inspect nursing homes to see if they are abiding by the regulations. In most instances, some form of wrongdoing is uncovered. These instances of wrongdoing, however, are not violations of criminal law or civil law; rather, they are violations of regulatory law. Hence, some authors focus on white-collar crimes as violations of regulatory laws.

Today, psychologists, criminologists and social scientists offer various ways to define white-collar crimes. Some of them are; Whitecollar crime as moral or ethical violations, White-collar crime as social harm, White-collar crime as violations of criminal law, White-collar crime as violations of civil law, White-collar crime as violations of regulatory laws, White-collar crime as workplace deviance, White-collar crime as definitions socially constructed by businesses, White-collar crime as research definitions, Whitecollar crime as official government definitions, White-collar crime as violations of trust, White-collar crime as occupational crimes and White-collar crime as violations occurring in occupational systems.

Criminologist Gary Green (1990) has been a strong advocate of focusing on occupational crime rather than a limited conceptualization of white-collar crime. He defined occupational crime as "any act punishable by law which is committed through opportunity created in the course of an occupation that is legal". Green described four varieties of occupational crime: (1) organizational occupational crimes, which include crimes by corporations, (2) state authority occupational crimes, which include crimes by governments, (3) professional occupational crimes, which include those crimes by individuals in upper class jobs, and (4) individual occupational crimes, which include those crimes committed by individuals in lower class jobs. The strength of his conceptualization is that it expands white-collar crime to consider all forms of misdeeds committed by employees and businesses during the course of employment.

White-collar crime can also be defined as violations occurring in occupational systems. This text uses such a framework to provide broad systems perspective about white-collar crime. White-collar crime can therefore be defined as "any violation of criminal, civil, or regulatory laws - or deviant, harmful, or unethical actionscommitted during the course of employment in various occupational systems." This definition allows us to consider numerous types of workplace misconduct and the interactions between these behaviors and broader systems involved in preventing and responding to white-collar crimes.
Determining the extent of white-collar crime is no simple task. Two factors make it particularly difficult to accurately determine how often white-collar crimes occur. First, many white-collar crimes are not reported to formal response agencies. One study found that just one third of white-collar crime victims notify the authorities about their victimization (Kane \& Wall, 2006). When individuals are victims of white-collar crimes, they may not report the victimization because of shame, concerns that reporting will be futile, or a general denial that the victimization was actually criminal. When businesses or companies are victims, they may refrain from reporting out of concern about the negative publicity that comes along with "being duped" by an employee. If victims are not willing to report their victimization, their victimization experiences will not be included in official statistics.

A second factor that makes it difficult to determine the extent of white-collar crime has to do with the conceptual ambiguity surrounding the concept. Depending on how one defines whitecollar crime, one would find different estimates about the extent of white-collar crime. The Government and other government agencies, offer different definitions of white-collar crime than many scholars and researchers might use. The result is that whitecollar crime researchers typically observe caution when relying on official statistics or victimization surveys to determine the extent of white-collar crime victimization. Despite this caution, the three main ways that we learn about the extent of white-collar crime are from official statistics provided by Government agencies, victimization surveys and research studies focusing on specific types of white-collar crime.

\section{Types of Crimes}

There are different types of crimes and some of them are as under:

The below mentioned diagram represents the areas covered by white-collar crimes. There are a number of lenses through which we can observe white-collar criminality. White-collar crimes have destructed Societies, Governmental Agencies, Government Departments and Non-Governmental Organizations in general.

\section{Criminal Behavior}

Criminal behavior suggests a large number and variety of acts. Andrew and Bonta (1998) suggested four broad definitions of Criminal behavior, acts and behaviors. These four areas are Legal Criminal Behavior or actions that are prohibited in the state and punishable under the law. Moral Criminal Behavior which refers to actions that violate that violates the norms of religion and morality and is believed to be punishable by a supreme spiritual being. Social Criminal Behavior which refers to actions that violates the norms of custom and tradition and are punishable by a community. Psychological Criminal Behavior that refers to actions that may be rewarding to the actor but inflict pain or loss on others. It is Criminal Behavior that is anti-social behavior. A risk factor for criminality is anything in a person's psychology, developmental or family history that may increase the likelihood that they will become involved in some point in criminal activities. A protective factor is anything in a person's biology, psychology, developmental or family history that will decrease the likelihood that they will become involved in criminal activity. Risk factors generally include: lower class origin, family of origin, poor personal temperament, lower aptitude, early behavioral histories, poor parenting, school based factors, poor educational/vocational/socio- 
Table 1. Evolution of the White-Collar Crime Concept

\begin{tabular}{|c|c|c|}
\hline Concept & Definition & Reference \\
\hline Criminaloid & $\begin{array}{l}\text { The immunity enjoyed by the perpetrator of new sins has brought into being a class for } \\
\text { which we may coin the term criminaloid. By this we designate such as prosper by flagitious } \\
\text { practices which have not yet come under the effective ban of public opinion. Often, indeed, } \\
\text { they are guilty in the eyes of the law; but since they are not culpable in the eyes of the public } \\
\text { and in their own eyes, their spiritual attitude is not that of the criminal. The lawmaker may } \\
\text { make their misdeeds crimes, but, so long as morality stands stock-still in the old tracks, they } \\
\text { escape both punishment and ignominy. }\end{array}$ & $\begin{array}{l}\text { E.A. Ross (Sin } \\
\text { and Society, } 1907 \text {, } \\
\text { p. } 48)\end{array}$ \\
\hline $\begin{array}{l}\text { White-collar } \\
\text { crime }\end{array}$ & $\begin{array}{l}\text { Crime committed by a person of respectability and high social status in the course of his } \\
\text { occupation. }\end{array}$ & Sutherland (1949) \\
\hline $\begin{array}{l}\text { Corporate } \\
\text { crime }\end{array}$ & $\begin{array}{l}\text { Offenses committed by corporate officials for their corporation and the offenses of the } \\
\text { corporation itself. }\end{array}$ & $\begin{array}{l}\text { Clinard and Yeager } \\
(1980, \text { p. } 189)\end{array}$ \\
\hline $\begin{array}{l}\text { Occupational } \\
\text { crime }\end{array}$ & $\begin{array}{l}\text { Offenses committed by individuals in the course of their occupations and the offenses of } \\
\text { employees against their employers. }\end{array}$ & $\begin{array}{l}\text { Clinard and Yeager } \\
(1980, \text { p. } 189) \text {. }\end{array}$ \\
\hline $\begin{array}{l}\text { Organiza- } \\
\text { tional devi- } \\
\text { ance }\end{array}$ & $\begin{array}{l}\text { Actions contrary to norms maintained by others outside the organization ... [but] supported } \\
\text { by the internal operating norms of the organization. }\end{array}$ & $\begin{array}{l}\text { Ermann and Lun- } \\
\text { dman }(1978, \text { p. } 7)\end{array}$ \\
\hline $\begin{array}{l}\text { Elite devi- } \\
\text { ance }\end{array}$ & $\begin{array}{l}\text { Acts committed by persons from the highest strata of society ... some acts are crimes ... } \\
\text { may be criminal or noncriminal in nature. }\end{array}$ & $\begin{array}{l}\text { Simon }(2006, \mathrm{p} . \\
12)\end{array}$ \\
\hline $\begin{array}{l}\text { Organiza- } \\
\text { tional crime }\end{array}$ & $\begin{array}{l}\text { Illegal acts of omission or commission of an individual or a group of individuals in a formal } \\
\text { organization in accordance with the operative goals of the organization, which have serious } \\
\text { physical or economic impact on employees, consumers, or the general public. }\end{array}$ & $\begin{array}{l}\text { Schrager and } \\
\text { Short, }(1978, \mathrm{p} \text {. } \\
408)\end{array}$ \\
\hline $\begin{array}{l}\text { Occupational } \\
\text { crime }\end{array}$ & $\begin{array}{l}\text { Any act punishable by law which is committed through opportunity created in the course of } \\
\text { an occupation that is legitimate. }\end{array}$ & Green (1990) \\
\hline
\end{tabular}

Figure 1. Defining White-Collar Crime

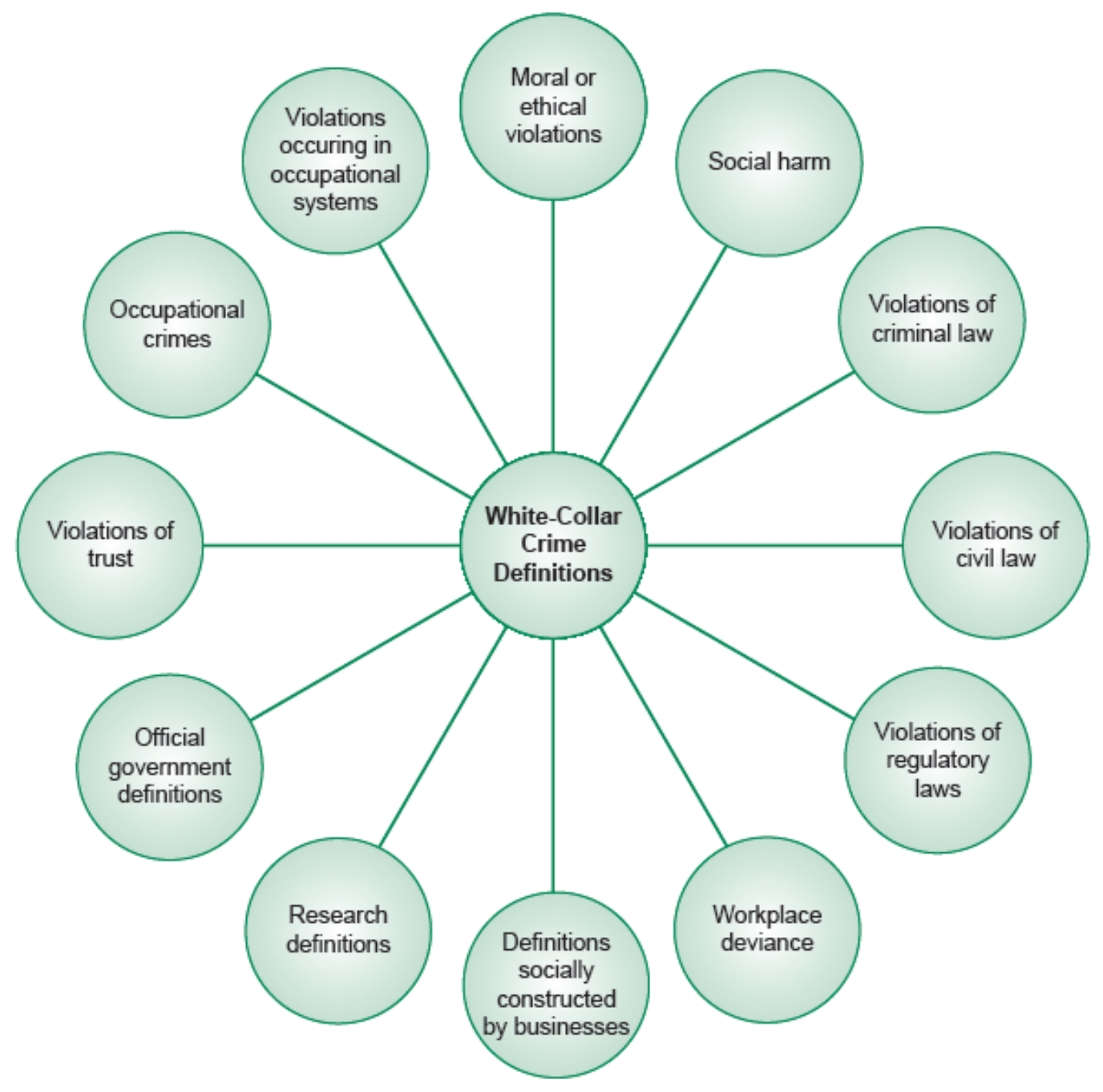


economic achievement, poor interpersonal relationships, antisocial associates which support crime, antisocial attitudes/values/ beliefs and feelings and psychopathology.

Delinquency must be distinguished from criminality. Delinquency is defined as behaviour that is illegal, immoral or deviant with respect to societal values. Criminality on the other hand is defined as a breaking of existing laws, there is little or no confusion as to what constitutes illegal and legal.

Walter Miller (1958) Theory of Focal Concerns describes the criminal behavior of lower Socio-economic status teen age gangs in terms of the values and expected norm of the Gang subculture.

\section{Consequences of White-collar crime}

Crime, by its very nature, has consequences for individuals and communities. White-collar crime, in particular, has a set of consequences that may be significantly different from the kinds of consequences that arise from street crimes. In particular, the consequences can be characterized as (1) individual economic losses, (2) societal economic losses, (3) emotional consequences, (4) physical harm, and (5) "positive" consequences.

Individual economic losses refer to the losses that individual victims or business lose due to white-collar crimes. One way that criminologists have captured these losses is to compare them to losses experienced by victims of conventional crimes.

Societal economic losses entail the total amount of losses incurred by society from white-collar crime. These costs are increased when considering the secondary societal economic costs such as business failures and recovery costs. In terms of business failures, one estimate suggests that one third to one half of business failures are attributed to employee theft (National White Collar Crime Center, 2009).

Emotional consequences are also experienced by victims of white-collar crime and all members of society exposed to this misconduct. These emotional consequences include stress from victimization, violation of trust, and damage to public morale. With regard to stress, any experience of victimization is stressful, but the experience of white-collar crime victimization is believed to be particularly stressful. Much of the stress stems from the violation of trust that comes along with white-collar crimes.

According to Sutherland (1941), the violation of trust can be defined as the "most general" characteristic of white-collar crime. Victims of a street robbery didn't trust the stranger who robbed them in the first place. Victims of a white-collar crime, in addition to the other losses incurred from the victimization, have their trust violated by the offender. There is reason to believe that the level of trust may be tied to the specific level of trust given to different types of white-collar offenders (e.g., we trust doctors and pharmacists at a certain level, but auto mechanics on another level).

With regard to public alienation, violations of trust potentially do damage to the economy and social relationships. According to Frankel (2006), "with few exceptions, trust is essential to economic prosperity" (p. 49). If individuals do not trust financial institutions, they are not likely to invest their funds in the economy. Sutherland (1941) recognized this relationship between trust, the economy, and social relationships. He observed-that the financial loss from white-collar crime is great and it is less important than the damage to social relations. White-collar crime violates trust and therefore creates distrust; this lowers social morale and produces disorganization. Many white-collar crimes attack the fundamental principles of the American institutions. Ordinary crimes, on the other hand, produce little effect on social institutions or social organization. (p. 13).

Building on Sutherland's ideas, Moore and Mills (1990) described the following consequences of white-collar crime: Diminished faith in a free economy and in business leaders, Erosion of public morality, Loss of confidence in political institutions, processes, and leaders.

Physical harm may also result from white-collar crime victimization. Sometimes, physical harm may be a direct result of the white-collar offense. For example, cases of physical or sexual patient abuse will result in physical harm for victims. Other times, experiencing financial harm can lead to physical problems. The loss of one's entire retirement savings, for example, has been found to contribute to health problems for white-collar crime victims (Payne, 2005).

Death or serious physical injury is also a possible consequence of white-collar crimes. In one case, for instance, seven people died after a doctor "used lemon juice instead of antiseptic on patients' operation wounds" (Ninemsn Staff, 2010). In another case, Reinaldo Silvestre was running a medical clinic in Miami Beach when it was discovered that he was practicing without a license, using animal tranquilizers as sedatives for humans, and performing botched surgeries. In a widely publicized case, a male body builder was given female C-cup breast implants-he had requested pectoral implants to make his chest look bigger ("Fugitive Phony Doctor Nabbed," 2004). It is possible to more generally highlight the physical harm stemming from white-collar crime.

Sociologist Emile Durkheim has highlighted four functions of crime that illustrate how crime in some ways has positive influences on individuals and communities (see Martin et al., 2009). These four functions can also be applied to white-collar crime. They include: warning light syndrome, boundary maintenance, social change, and community integration.

The warning light syndrome refers to the fact that outbreaks of white-collar crime could potentially send a message to individuals, businesses, or communities that something is wrong in a particular workplace system. If an outbreak of employee theft occurs in a hospital, for example, the administrators would be warned that they need to address those aspects of the occupational routines that allowed the misconduct to occur.

In terms of boundary maintenance, it is plausible to suggest that individuals learn the rules of the workplace when some individuals are caught breaking those rules. In effect, they learn the boundaries of appropriate and acceptable behaviors by seeing some individuals step over those boundaries. Some even recommend that white-collar offenders, when caught, be arrested at times when the vast majority of workers would be able to see the arrests (Payne \& Gray, 2001). This recommendation is promoting a strategy to promote boundary maintenance.

With regard to social change, our society has changed significantly because of white-collar misdeeds. Some people have talked 
about how survivors of violent crime actually become stronger because of their experience with violence. Following this same line of thinking, those who survive white-collar crime victimization might actually become stronger. As well, when cultures and societies survive corporate victimiza-tion, they too may actually grow stronger.

Community integration is a fourth function of white-collar crime. In particular, groups of individuals who otherwise would not have become acquainted with one another may come together in their response to white-collar crime. When there is a crime outbreak in a neighborhood, those neighbors come together to share their experiences and make their neighborhood stronger (Martin et al., 2009). A crime outbreak in a business could have the same result. Coworkers who never talked with one another might suddenly become lunch buddies simply because they want to get together to talk about the crimes that occurred in their workplace. As well, at the societal level, new groups have been formed to prevent and respond to white-collar crime.

\section{White-collar crimes in Jammu \& Kashmir}

Undoubtedly today's Kashmir is a very different Kashmir with all forms of traditional as well as new forms of crime ranging from murders, rapes, thefts to cyber frauds, white collar crimes, etc. The increasing immorality and relates budding criminality to the ongoing conflict situation and treats the presence of large number of security forces, Machiavellianism, corruption and lack of proper policing is responsible for the emerged crime atmosphere. While exploring new trends of crimes in Kashmir, the particular emphasis is on crimes related to women, crimes related to business in Srinagar, role of police in dealing with crimes and criminals, property crimes like thefts, rapes, murders, etc. The Ministry of Home Affairs mentioned in its annual report that as many as 1,667 military related incidents were reported in the year 2006. Simultaneously, the state department says that 23,492 cases of crimes were registered during the same year; out of these a total of 21,825 cases were related to normal policing as claimed by a senior police officer. J\&K has a $26.6 \%$ share of violent crimes out of $11.1 \%$ of an average national level of the total IPC crimes. Criminals are ever more resourceful in their methods and they take full advantage of the range of criminal opportunities presented. These include the trafficking of drugs, property crimes, cyber frauds, human trafficking, gang crimes, terrorism and crimes related to different occupations etc.

In today's scientific world, the state of Jammu and Kashmir is progressing towards scientific developments in multiple areas of work. One side J\&K Government is trying to use advanced technologies in different departments to make work easier and comfortable for its employees another side some officials are involved in white-collar crimes which destructed the future of younger generations e.g. In an investigation regarding the scandal involving sale of entrance exam papers by Board of Professional Entrance Examinations (BOPEE) chairman Mushtaq Ahmed Pir, some new developments have come to the fore. Enforcement Directorate has confiscated assets worth Rs 60 lakh belonging to Mushtaq Ahmad Pir, the former Chairman Board of Professional Entrance Examination (BOPEE) who is also the main accused in this case. The assets that have been attached by the ED include various immovable properties Sidhra and Wazarat Road Jammu and one property in Delhi. Besides, attaching immovable property of the tainted official, Enforcement Directorate has also seized his bank accounts and the cash up to the tune of Rs 10 lakh lying with different banks. A bank account belonging to her daughter has also been seized by the Enforcement Directorate. ED official said that Pir had used the bank account of his daughter to transfer the money.

"During investigation it was revealed that the broker Farooq Itoo had earned Rs 73 lakhs from the CET paper selling scam out of which he had paid Rs 60,000 to the Mushtaq Ahmed Pir, said the officials. On the face of it, these disclosures look very superficial and flimsy. It is well known that this scandal, which came to light in November 2013, was quite big in scale. BOPEE, after facing strong indictment from the High Court had to cancel the admission of the twelve students who according to Crime Branch had purchased Common entrance test questions in 2012.

The other example will be related to the Computer Auditor General (CAG) Dr. Subhash Chandera Pandey who has raised question marks over the commitment of the State Government of Jammu and Kashmir in fighting against the 25000 Crore Roshini Corruption Scandal (2007). There are multiple areas of work in which white-collar crimes related to ministers, employees and as well as upper class of society will be identified and presented in literature.

\section{Public Attitude about White-collar crime}

A large body of criminological research has focused on public attitudes about crime and different crime policies. Unfortunately, of the hundreds of criminological studies focusing on attitudes about crime, only a handful have focused on what the public thinks about white-collar crime. Yet research on white-collar crime attitudes is important for empirical, cultural, and policydriven reasons (Piquero, Carmichael, \& Piquero, 2008). In terms of empirical reasons, because so few studies have considered what the public thinks about white-collar crime, research on this topic will shed some light on how members of the public actually perceive this offense type. As well, such research will provide interesting, and important, insight into a particular culture or subculture. Perhaps most important, such research provides policy makers information they can use to implement prevention, response, and sentencing strategies.

In one of the first studies on public attitudes about white-collar crime, Cullen and his colleagues (Cullen, Clark, Mathers, \& Cullen, 1983) surveyed a sample of 240 adults and assessed various perceptions about this behavior. The researchers found that the sample (1) supported criminal sanctions for white-collar offenders, (2) viewed white-collar crimes as having greater moral and economic costs than street crimes, and (3) did not define the offenses as violent. They also found that perceptions of seriousness of white-collar crime increased more than any other offense type in the 1970s and those physically harmful offenses were viewed as the most serious forms of white-collar crime.

Other studies have shown similar results. A study of 268 students found that perceptions of the seriousness of white-collar crime have increased over time and that these perceptions were tied to wrongfulness and harmfulness (Rosenmerkel, 2001).The NW3C National Victimization Survey also included items assessing perceptions of seriousness. The researchers found that the sample of 1,605 adults viewed (1) white-collar crime as serious as conventional crime, (2) physically harmful white-collar offenses as more serious than other white-collar crimes, (3) organizational offenses as more serious than individual offenses, and (4) offenses by high- 
er status offenders as more serious than offenses by lower status offenders (Kane \& Wall, 2006).

More recent research has built on these findings. A telephone survey of 402 residents of the United States focused on perceptions about white-collar crime and the punishment of white-collar offenders (Holtfreter, Van Slyke, Bratton, \& Gertz, 2008). The authors found that one third of the respondents said that whitecollar offenders should be punished more severely than street criminals. They also found that two thirds of the respondents believed that the government should "devote equal or more resources towards white-collar crime control” (p. 56).

Telephonic interviews on white-collar crimes with 1,169 respondents found that the majority of respondents defined white-collar crime as equally serious as, if not more serious than, street crime (Piquero, Carmichael, \& Piquero, 2008). They also found that the presence of a college education impacted perceptions of seriousness. Those with a college education were more likely to define street crime and white-collar crime as equally serious. Another study using the same dataset found that respondents believed that street criminals were more likely than white-collar offenders to be caught and to receive stiffer sentences (Schoepfer, Carmichael, \& Piquero, 2007). Respondents also believed that robbery and fraud should be treated similarly. Another way to suggest this is that the respondents believed that robbers and occupational offenders committing fraud should be handled the same way. In addressing this point, it is important to call attention to similarities and differences between conventional criminals and white-collar criminals.

\section{Criminal Psychology}

Criminal psychology is an important area of applied psychology. While it draws on other disciplines, it has its own unique body of research using an integrative approach and addresses questions and issues that no other discipline in psychology explores. Examples include: risk assessment with respect to the potential for violence; criminal behaviour, aggression, and juvenile delinquency; jury behaviour and selection; the accuracy of eyewitness testimony; the psychology of confessions and false confessions; the dimensions and assessment of legal competency and insanity; domestic violence and family law including custody evaluations; prevention and treatment of antisocial behaviour.

\section{Conclusion}

In Jammu and Kashmir state white-collar crimes are increasing tremendously and because of these crimes J\&K is one of the top most corrupted states of India. White-collar crimes and related abuses are not adversaries that can be targeted, met, attacked, and defeated once and for all. They are, rather, forms of group behavior that can be expected to surface again and again in response to new opportunities, or to avoid the loss of money, property, markets, or personal advantages. Since total victory and perpetual safety are not attainable, society's general objective in this area should be to marshal and deploy its public and private administrative, research, and law enforcement resources to contain whitecollar crime, that is, to deter, detect, investigate, and prosecute (criminally and civilly) these crimes and related abuses. Many resources exist that have not been fully brought to bear on this area. In the academic community, schools of business have totally ignored the problem of white-collar crime; law schools, with rare exceptions, treat the problem as a very minor part of courses in criminal law and regulatory law; social scientists have noted the problems in this field but have not yet developed methods to gather, organize, and describe white-collar criminal behavior or measure the effectiveness of remedies.

\section{Acknowledgements}

We thank to Research Scholar Ms. Tamanaah, Ganie Zahoor and Prof. S.S.Bali (Aasra Jammu J\&K).

\section{References}

[1] Aubert, Vilhelm (1952) 'White-Collar Crime and Social Structure'. American Journal of Sociology 58: 263-71.

[2] Braithwaite, John (2001) 'Conceptualizing Organizational Crime in a World of Plural Cultures', in Henry Pontell and David Shichor (eds) Contemporary Issues in Crime and Criminal Justice: Essays in Honor of Gilbert Geis. 17-32.

[3] Bryant, Clifton D. (1974) Deviant Behavior: Occupational and Organizational Bases. Chicago.

[4] Clinard, Marshall B, Richard Quinney (1973) Criminal Behavior Systems: A Typology. New York: Holt, Rinehart \& Winston.

[5] Douglas, Jack D, John M. Johnson (1977) Official Deviance. New York: J.B. Lippincott Co.

[6] Ermann M. David, Richard J. Lundman (1996) Corporate and Governmental Deviance, $5^{\text {th }}$ edn. New York: Oxford University Press.

[7] Friedrichs, David O. (1992) 'White Collar Crime and the Definitional Quagmire: A Provisional Solution', Journal of Human Justice 3(3): 5-21.

[8] Friedrichs, David O. (1996a) Trusted Criminals: White Collar Crime in Contemporary Society. Belmont, CA: ITP/Wadsworth Publishing Co.

[9] Friedrichs, David O. (1996b) 'Defining White Collar Crime: In Defense of an Inclusive Approach', in James Helmkamp, Richard Ball and Kitty Townsend (eds) Definitional Dilemma: Can and Should There Be a Universal Definition of White Collar Crime?, pp. 263-74.

[10] Geis, Gilbert (1962) 'Toward a Delineation of White-Collar Offenses', Sociological Inquiry 32(Spring): 160-71.

[11] Geis, Gilbert (1982) On White-Collar Crime. Lexington, MA: Lexington Books.

[12] Geis, Gilbert (1992) 'White-Collar Crime: What Is It?', in Kip Schlegel and David Weisburd (eds) White-Collar Crime Reconsidered, pp. 31-52.

[13] Geis, Gilbert (2002) 'White-Collar Crime', in Gary W. Potter (ed.) Controversies in White Collar Crime, pp. 37-52.

[14] Gerring, John (1999) 'What Makes a Concept Good? A Criterial Framework for Understanding Concept Formation in the Social Sciences', Polity 31(3): 357-93.

[15] Gibbons, Don C. (1983) 'Typologies of Criminal Behavior', in Sanford H, Kadish (ed.) Encyclopedia of Crime and Justice 1572-6.

[16] Green, Gary (1997) Occupational Crime. Chicago, IL: Nelson-Hall Publishers.

[17] Green, Gary (2001) 'Occupational Crime', in David Luckenbill and Dennis Peck (eds) Encyclopedia of Criminology and Deviant Behavior. Volume II, Crime and Juvenile Delinquency 404-9.

[18] Helmkamp, James, Richard Ball, Kitty Townsend (1996) White Collar Crime: Definitional Dilemma: Can and Should There Be a Universal Definition of White Collar Crime? Morgantown, WV: National White Collar Crime Center.

[19] Ismaili, Karim (2001) 'Workplace Crime', in David Luckenbill and Dennis Peck Encyclopedia of Criminology and Deviant Behavior. Volume II: Crime and Juvenile Delinquency 530-3.

[20] Meier, Robert F. (2001) 'Geis, Sutherland, and White-Collar Crime', in Henry N. Pontell and David Shichor Contemporary Issues in Crime and Criminal Justice: Essays in Honor of Gilbert Geis 1-16.

[21] Miethe, Terance D, Richard C. McCorkle (2001) 'Typologies of Crime', in David Luckenbill and Dennis Peck Encyclopedia of Criminology and Deviant Behavior 508-11.

[22] Pino, Nathan W. (2001) 'Occupational Deviance', in Patricia A. Adler, Peter Adler and Jay Corzine Encyclopedia of Criminology and Deviant Behavior. Volume I: Historical, Conceptual, and Theoretical Issues 260-5.

[23] Quinney, Richard (1964) 'the Study of White Collar Crime: Toward a Reorientation in Theory and Research', Journal of Criminal Law, Criminology and Police Science 55: 208-14.

[24] Robin, Gerald (1974) 'White-Collar Crime and Employee Theft', Crime and Delinquency 20(3): 251-62.

[25] Simon, David R. (1999) Elite Deviance, $6^{\text {th }}$ edn. Boston, MA: Allyn \& Bacon.

[26] Southerland, Mittie D, Pamela A. Collins, Kathryn E. Scarborough (1997) Workplace Violence: A Continuum from Threat to Death. Cincinnati, $\mathrm{OH}$ : Anderson.

[27] Sutherland, Edwin H. (1940) 'White-Collar Criminality', American Sociological Review 5:1-12.

[28] Sutherland, Edwin H. (1949) White Collar Crime. New York: Holt, Rinehart \& Winston. 